Отримано: 08 липня 2019 р.

Прорецензовано: 11 липня 2019 р.

Прийнято до друку: 15 липня 2019 р.

e-mail: king24@ukr.net

DOI: $10.25264 / 2415-7384-2019-9-9-15$
Volodymyr Savchuk. The interrelation between national self-consciousness and historical myths. Наукові записки Національного університету «Острозька академія». Серія «Психологія» : науковий журнал. Острог : Вид-во НаУОА, серпень 2019. № 9. C. 9-15.

\author{
Volodymyr Savchuk, \\ postgraduate student at the Department of Psychology and Pedagogics \\ Ostroh Academy National University
}

\title{
THE INTERRELATION BETWEEN NATIONAL SELF-CONSCIOUSNESS AND HISTORICAL MYTHS
}

\begin{abstract}
The paper encompasses the overview of the major approaches to definition and structure of national self-consciousness and the historical myth. It analyses the essence and the aspects of the reciprocal influence of both phenomena studied. The author indicates the correlation between them on the basis of mythological perception and the development of one's individual identity. The role of the integrative function of historical myth is studied as well as the effect its contrastive aspect has on a person's national self-consciousness. The paper includes the characterization of archetypes and symbols together with images of heroes in the axiological sphere. The author studies the impact the history and geography of a nation has on the national self-consciousness. Also, the position which national character and national idea have in the structure of national self-consciousness in the context of the influence of historical myth is analyzed.
\end{abstract}

Key words: national self-consciousness, historical myth, ethnic stereotype, autosterotype, national character.

\author{
Савчук Володимир Андрійович, \\ аспірант кафедри психології та педагогіки \\ Національного університету «Острозька академія»
}

\section{ВЗАЄМОЗВ'ЯЗКИ МІЖ НАЦІОНАЛЬНОЮ САМОСВІДОМІСТЮ ТА ІСТОРИЧНИМИ МІФАМИ}

\begin{abstract}
У статті розглянуто основні підходи до визначення та структури начіональної самосвідомості й історичного міфу. Проаналізовано характер та аспекти взаємовпливу досліджуваних явищ. Виявлено зв 'язок між ними на основі міфологічного світосприйняття та становлення індивідуальної ідентичності. Визначено роль інтегративної функиії історичного міфу та ї̈ контрастивного аспекту в розвитку національної самосвідомості. Схарактеризовано специфіку архетипів та символів, а також образів героїв в аксіологічній площині й досліджено вплив історичного минулого та географії розселення на особливості національної самосвідомості. Крім того, проаналізовано місце національного характеру та національної ідеї у структурі національної самосвідомості в контексті впливу історичного міфу.
\end{abstract}

Ключові слова: національна самосвідомість, історичний міф, етнічний стереотип, автостереотип, національний характер.

Identification of research problem. The issue of national self-consciousness remains highly relevant due to the constant need for devoted patriots who can make a vast contribution to development of their state and, what is more important, of whole humanity. The high level of national self-consciousness implies respectful attitude to other nations, which is vital in the context of cross-cultural communication. Moreover, it is national self-consciousness which is commonly attacked in the course of informational warfare. The diverse armory is available in this kind of conflict and historical myths are part of it. Often, it is the history of the nation that unifies its representatives promoting national identity. However, historical myths do not always have a negative effect but can also facilitate the unity of the nation and bolster the national self-consciousness.

Brief overview of previous research. Despite being numerous, works on the notions studied majorly focus on one of them and rarely they combined both. For instance, Barkanova, Borysov, Boryshevskyi, Shuhai and Sokolova explored the psychological nature of national self-consciousness. Ethnic identity was studied by Arutyunov, Lebon, Romanucci-Ross, and Streth. Kulchytskyi analyzed Ukrainian national character. Hyrych, Shapoval, Yas and Hryhoriiv researched historical myth. Koval and Romanenko focused on the use of myths in conflict while Barthes, Berdyayev, and Chyzhevskyi took a more philosophical approach. Freud and Jung explored myth in the context of psychoanalysis, and May examined it from the angle of existential psychology. Finally, Hosking, Schopflin, Segesten, and Torrecilla researched the impact of myth on national identity.

The aim of the paper is to analyze the mutual connection of national self-consciousness and historical myths identifying the specific aspects of this interrelation. 
The materials and methods of the present study. Within the framework of the given research the following methods were employed: analysis, comparison, systematic approach, formalization and inductive method.

The body of the paper. Even in the era of globalization, the significance of national self-consciousness is evident in the light of the fact that human civilization exists not in general and universal terms but in particular national instances [7]. Before starting the research on the interrelation between national self-consciousness and historical myths, it is important to define both concepts paying due attention to their structure. According to Boryshevskyi and Sokolova, national self-consciousness is an individual's self-realization as a part of a specific national or ethnic community and their self-evaluation as a holder of national or ethnic values which have been formed in the process of the society's continuous historical progress and fulfilment of its potential as a subject of social activities [6;14]. It can be characterized by the need to express and fulfil one's national nature and uniqueness, take one's own place among other national communities, and make a contribution to the advance of human history. Moreover, the key psychological prerequisites for national self-consciousness actualization are realization of one's own nation through the viewpoint of other nations' representatives and axiological attitude to national constructs [5].

Sphere-based approaches to the structure of national self-consciousness by Barkanova and Shuhai rely on the same principles, and still differ slightly: both theories include cognitive and affective aspects, but Barkanova focuses on conative filed while Shuhai singles out regulative element $[2 ; 17]$. On the other hand, if to concentrate on the psychological phenomena the notion encompasses rather than the spheres it functions in, the structure will include four components. Boryshevskyi outlines self-esteem, aspiration, socio-psychological expectations, and self-concept as parts of national self-consciousness [6]. Self-esteem is a person's judgement about their qualities in comparison with certain standards which represent the system of national values of the society the person identifies with. Being characterized by the parameters of its reasonableness, level, stability and degree of selfcriticism, self-esteem is responsible for feeling of superiority or inferiority a person can have when compared to representatives of their own or other nations. Aspiration signifies one's determination to choose personally significant goals which are defined by the system of ethnic or national values. The achievement of these goals can satisfy one's need to take the desired place on the scale of these values. Socio-psychological expectations are closely connected with both axiological sphere and aspirations of a person as they are one's idea of how their environment appraises their possession of specific national values. Moreover, these expectations concern the behavior the person is supposed to exhibit. Finally, a self-concept is a high-level generalization of a personality's vision of themselves as a holder of particular ethnic or national values.

It is also important to take into account the indicators of harmonious high-level national self-consciousness as their presence or absence can signify the influence of certain factors, among them being historical myths. First, it is national identity, which is a person's realization of their belonging to a distinct ethnos or nation together with realization of their closeness and affinity with the nation. Second, it is the knowledge of typical features and peculiarities of the national community which an individual identifies themselves with. Furthermore, it appears more visible if completed with the knowledge of other nations' features paving the way for contrast. Third, it is conscious attitude to the historical past, present and future of the ethnos or nation. Fourth, it is understanding of the notion of the nation's territorial integrity and respect for it. Finally, the high level of national self-consciousness can be testified by a mindful and conative approach to the nation's material and spiritual values together with a stable need for their enrichment as well as being oriented towards the leading values of the nation in one's life [6].

The development of a person's national self-consciousness can be influenced by different types of myths, including historical ones. Hyrych and Shapoval define historical myth as a system of positive appraisals of heroes and events of the past which are the base for present-day national policy and national liberation movement [8]. Historical myth can be interpreted as a specific and often deformed historical consciousness. Yas argues that in this case emotional and intuitive psychological elements (e.g. images and symbols) are used in order to share the knowledge for explaining processes, events, facts and phenomena of the past [22]. At the same time, the irrational components are combined with selected elements of logical and rational clarification. Considering the notion of myth more generally, Romanenko states that it is the name of an object which induces a particular image in one's consciousness [13]. Moreover, Barthes suggests that despite being based on human history, myth cannot actually take place as its mechanism is not deception but deviation [6]. Therefore, rather than concealing or demonstrating something, myth distorts it. The structure of historical myth encompasses the following parts: national messianism, a distinct historical path, collective spirit of the nation, opposition between the interest of a given nation and the national interests of a ruling nation, and, finally, call for establishment of autonomous order within the conqueror state [8].

A clear connection between national self-consciousness and historical myths is demonstrated by the peculiarities of phases of national self-consciousness formation. Borysov claims that the first stage concerns preschoolers and school-aged children, and is characterized by mythological perception of one's national nature [5]. May assumes that myth often fulfils a preservation function for a child's mind [23]. Having a soothing 
effect, even when involving cruel facts, myth induces less pain than the historical event itself. Consequently, combining both pleasant and discomforting experiences, myth develops a set of patterns a person can relate to. Segesten asserts that apart from explanatory function, myths play their role in shaping one's individual identity [26]. Furthermore, Torrecilla states that myths mold a person's identity by means of determining socially accepted behavior [29]. The significance of cultural development of a person must not be neglected as formation of one's patterns of interaction with their environment is conditioned by the understanding of the world that their cultural experience provides [5]. Finally, the images of a myth are identification models that perform a socialization function for an individual, who unconsciously reenacts the acquired structures in their life [10].

The sense of national affinity develops since childhood. The first phase of national self-consciousness defined by Borysov is indicated by unclear realization of a child's bounds with representatives of their nationality, unreasoned choice of their national identity, and poor knowledge of the national world [5]. Subsequently, national self-consciousness is shaped along with the system of cultural peculiarities of a given nation (its origin, traditions, and folklore) and identification with the community. The next stage relies on the system of nation's psychological features such as national character, national temperament, specific aptitudes, national feelings, interests, etc., and thus allowing the person to realize themselves as a national subject. These prerequisites of national self-consciousness together with its reflexive nature are closely connected with the notion of myth. Myth can be defined as a narrative which illustrates a community's view of itself [17]. Moreover, applying a conventionalist approach, Seton-Watson argues that it is enough for a community to consider that it has created a separate nation or to behave as if it has done it (i.e. adopting a myth), for a new nation to be born [27]. Finally, May also attributes a strong integrative function to myth [23].

One of indispensable elements of national self-consciousness which unifies the society is national idea. A national idea is the most relevant and advanced goal which is realized by the nation, the achievement of which allows the nation to fulfil its potential and make a serious contribution in the advance of human civilization and occupy its place among other nations [6]. Therefore, for unification purposes national idea combines both identification with the representatives of the same nation and differentiation form those belonging to other national communities. Regarding the stages of national self-consciousness development, "we/they" contrast plays a leading role in national identification formation on the first (preschoolers and school-aged children) and the fourth (youth) phases [5]. Similarly, according to Streth myth is a narrative which strengthens the connection within the "we" group and detaches it from the "they" group [28]. In fact, May takes a step further and points out that the members of our community are defined by cherishing the same myths as we do while a stranger is anyone who does not share our myths [2].

Referring to Borysov's research on displays of national self-consciousness, it is possible to single out those that strongly affect a person's opinion on representatives of other national groups and can consequently be a result of myth influence [5]. The displays majorly concern the types of self-identification which could be positive, reasonable, and negative. The high level of positive self-identification conditions superpositive appraisal of one's own psychological features and negative emotional and evaluative attitude to those belonging to other nations. On the contrary, reasonable self-identification leads to bolstering the society's unity and optimization of cross-ethnic interaction.

National character (or the collective spirit of a nation, as stated by Hyrych and Shapoval [8]) is one more factor that plays its role within this "we/they" dichotomy. By Sokolova's definition, national character is a historically developed complex of stable psychological traits of a nation which determine the usual behavior and typical lifestyle as well as its attitude to labor, other nations, and its own culture [14]. Messianistic views, which are commonly a feature of national character, can be caused by nation's traumatic historical past which generated the inferiority complex. Kulchytskyi suggests that it is induced by the strong need to compensate for the past pain by means of placing an excessive emphasis on the nation's own power and significance, which is common for newly independent states [11].

National messianism is also dangerous due to the fact that it can engender the rise of superiority myth which justifies the imperial views (e.g., the "civilizing" of America's indigenous people). In this case, the myth attributes the potential of threat to all the members of outgroup, therefore contributing to the collective identity and contains a hyperbolized image of an enemy (e.g., "savage") employing a set of ethnic stereotypes, which are schematized images of representatives of any ethnic community and are based on simplified and often inaccurate knowledge about psychological peculiarities and behavior of people of other nationality $[26 ; 14 ; 10]$. However, stereotypes in the sphere of national self-consciousness can also be both positive, especially considering autostereotypes. Borysov observes positive autostereotypes combined with low level of an individual's positive self-identification as a result of positive evaluation of the nation's psychological characteristics and the individual's identification with other representatives of the community [5]. Conversely, negative autostereotypes and attitudes can be indicated when a person shows medium level of negative self-identification. At any rate, stereotypes are perilous not only as they are difficult to eradicate but also since they tend to layer and thus preserve in everyday social consciousness [14]. 
Sokolova states that the type of traditionalism as a form and a way of ethno-cultural entity can be an integral indicator of an ethnic group [14]. Significantly, such a factor is archetypal, which makes the sphere of the unconscious a common area for national self-consciousness and historical myths. Jung maintains that archetypes stem from the repeated human experiences [21]. Such an approach allows to ascribe them to history drawing a connection with historical myths. Archetype is an unconscious element of an image which facilitates structuring and marking of surrounding phenomena and objects as well as serving as barriers in perception of the unknown [19]. Besides, archetype can be transferred from one national group to another (e.g., eternal student and heroic outlaw, both of which came to Ukrainian system from Byzantium and were adapted according to the local psychological culture). The irrational nature of myth is testified by Segesten as the original Greek term muthos is opposite to logical reasoning (logos) [26]. Moreover, Barthes highlights the impressive character of myth due to the fact that rational debunking is ineffective against it [3].

One more field where national self-consciousness and historical myth meet is a person's axiological system. The level of development of one's national consciousness and self-consciousness is determined by the extent to which the acquired socially significant values have become a part of system of their needs and motivation [6; 5]. Similarly, adoption of specific values (e.g., freedom) is one of the prerequisites of a myth formation (e.g., the myth of American individualism) [2]. Finally, Barthes proves the axiological potential of myth noting that it includes the whole set of values among them being history [3]. In fact, Sokolova reports a historical impact on value prioritization: being continuously subject to attacks from other nations, the Ukrainians found the notion of tranquility included in their axiological system [14].

For a more vivid representation of values, myths often contain their personal embodiments known as heroes. May assumes that people need personified role models and examples of behavior and morality which they can identify with [23]. As the first phase of national self-consciousness development is based on mythological views of the world, the child feels the need to feel connected with the wisdom of the nation and experience the deeds of "cultural heroes" which the person identifies with [5]. Concerning the national type, Chyzhevskyi suggests that it can be characterized in three ways [16]. First, it is the study of the nation's folklore. Second, one can outline the most prominent and remarkable historical epochs which the given nation has had. Third, it is characterization of the most outstanding representatives of the national group, its great figures.

History as an individual or collective view of the nation's past is the key sphere of interconnection between national self-consciousness and historical myths. By the definition Hyrych and Shapoval provide, myth is the broad masses' vision of their past, which was designed and introduced by the ideological machine or the political and intellectual elites [8]. The application of myths on the level of collective memory (a part of which being historical memory) paves the way for molding mass consciousness and national self-identification as well as gives the society the ability to differentiate itself from other communities. The historical memory lies in the core of unity of historical destiny and national feeling which is the main factor of nation creation.

Additionally, mythologization helps the nation see its place in the world [19]. The modern-day myths are being generated with the aim of explaining the past of the nation including events and its notable figures. These narratives are then employed to rally the nation, form the foundation for the future national identity, and produce distinctive features or an image of the given national group allowing it to discern itself from the others. In such a way, the semantic structure of myth becomes the historical a priori which determines the development of individual and social history alike [14]. Furthermore, Freud asserts that the semantic wholeness of myth is a starting point of research on historical imitation of cognitive forms which identify the person [15]. RomanucciRoss also notes that the national self-identification is rooted in the history [25]. Despite stemming from the past, it is fulfilled here and now on the basis of real functioning components of the surrounding world. The past is mainly objectified in the areas of language and culture as both of them are means of passing information to subsequent generations.

The role of history in the identification of nations is testified by Arutyuonov [1]. The study of nation-building becomes complicated if two national groups have common historical roots and share a series of cultural fields and elements due to long-lasting coexistence of both communities within a single completed historical and cultural system of their interrelations. Borysov maintains that establishing bounds with one's national world is the key process in the course of national self-consciousness development as in such a way the person receives national notions of the cultural environment and thus obtains a set of national and cultural means of their community [5]. Cultural mediation conditions the rise of national self-consciousness, which amasses an ideal component of national and cultural world of one's ancestors.

The influence of the events in national and world history on national self-consciousness cannot be overemphasized. For instance, the Napoleonic Wars spurred the feeling of unity and otherness of multiple European national groups [4]. Moreover, analyzing the typical traits of the Ukrainians, Chyzhevskyi focused on tragic and violent episodes of their history as the ground for specific negative psychological features of this nation [16]. However, this effect is reciprocal since on multiple occasions Ukrainian national character 
determined the course of the history of this group. In fact, according to Lebon's definition, history is the result brought by the psychological composition of races [12].

The territorial aspect of the studied interrelations is also worth mentioning taking into account the NationState-Land triad. Segesten suggests that when such type of historical myth as the foundation narrative incorporates the geographical element, the notion of anteriority plays the key role shaping the view of the national group [26]. The strong impact of historical myth on subjective world-representation is also highlighted by Hyrych and Shapoval [8]. Its primary function is to mobilize the nation around the idea of reconquering the land previously occupied by the ruling nation.

Additionally, in the scope of geographical determinism it is possible to observe the effect which the land can have on the national character. In particular, Chyzhevskyi states that steppe (the common landscape for South East Ukraine) symbolizes the greatness of the nation for Ukrainian mind [16]. Esthetic and religious feelings together with philosophical consciousness take a specific form while perceiving the steppe. Subsequently, it became a foundation for the rise of a legendary locus of the Wild Fields, famous for the Cossacks. Furthermore, Hryhoriiv believes that the vast expanses of Ukraine facilitated the development of such traits as indifference, passiveness, and placidity [9].

Finally, the territorial facet of national self-consciousness also concerns "we/they" differentiation directly affecting people's attitudes. Boryshevskyi points out that the understanding of a nation's territorial integrity and respect for it indicate the high level of national self-consciousness [6]. If the nation's self-esteem is incomplete or unreasonable, it induces the distorted national self-consciousness as can be seen in the case of ruling nations of empires. Claiming their own uniqueness and superiority, they have erroneous vision of their territorial rights, which generates the desire to appropriate the lands of the oppressed nations. Notably, such attitudes can preserve long after the demise of the empire, which can be exemplified by Russian ideology.

Altogether, it is possible to illustrate the key aspects of the overlap of national self-consciousness and historical myth in the Figure 1.

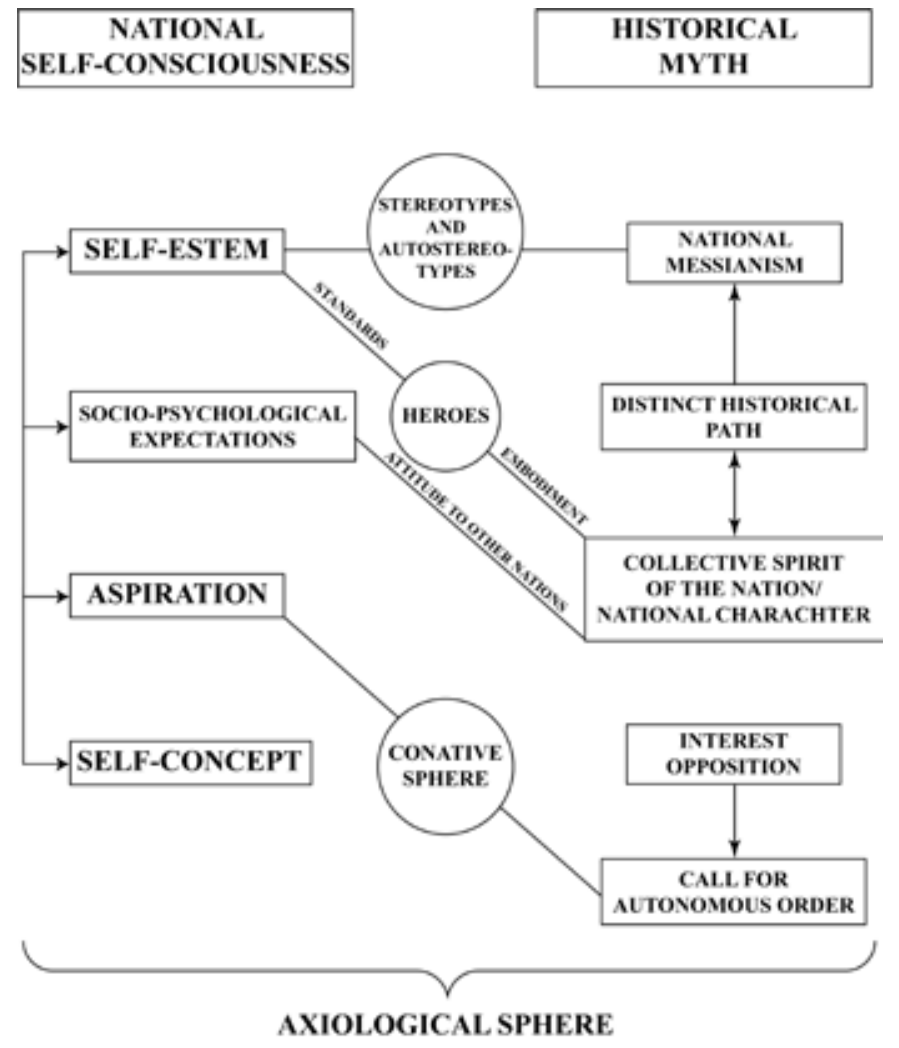

Figure 1. The interrelation between national self-consciousness and historical myth

As stated above, all four elements of national self-consciousness are interconnected. Contrastingly, all five elements of historical myth can be divided into two groups. In the first one, distinct historical path influences the feeling of national messianism (being a prerequisite for it) and at the same time mutually influences the collective spirit. The second group contains the interest opposition impacting the call for autonomous order, which is one of the most vivid forms of the former. Self-esteem can be modified by the messianistic element of historical myth with the help of stereotypes and especially autostereotypes (usually exaggeratedly positive ones). Moreover, self-esteem can also be effected by the collective spirit of the nation by means of heroes who are, on the one 
hand, standards for comparison in the national self-consciousness and, on the other hand, the embodiment of the very national character. The collective spirit also influences socio-psychological expectations through the set of attitudes to non-representatives of a given nation. Aspiration is linked with the call for the establishment of autonomous order by a conative sphere. Not being directly connected with the elements of historical myth, selfconcept is still influenced by it with the mediation of remaining three components of national self-consciousness. Finally, the interactions mentioned above mostly happen in axiological field as all components of both national self-conscience and historical myth appeal to the system of values.

Conclusions. Ultimately, the interconnection of national self-consciousness and historical myths can be observed in multiple aspects. The key points of national self-consciousness are identification with the community, reflexivity regarding possession of national values, and attitude towards the representatives of the outgroup. Historical myths can be characterized by the concepts of vision, explanation, and evaluation of the nation's past, which majorly has deformed nature. Taking into account these aspects, it is possible to define the mythological perception of national elements in children of pre-school and school age as one of the crucial areas of interrelation of the studied phenomena. Historical myth takes part in shaping a person's individual identity helping them to answer the question "Who am I?" Both notions are connected on the basis of fulfilling the integrative function and separate those who do not belong to the given national group. It can be vividly observed in the case of negative attitude towards the others with the employment of ethnic stereotypes and enemy demonization. A wide range of archetypes and symbols which national self-consciousness is based on are applied in historical myths as well as a system of national heroes used as paragons. The nation's shared vision of its history and territory is another common aspect as it assists in finding the nation's place in the world, temporally and spatially alike. However, it is important to highlight the reciprocity of influence the course of history has on the national self-consciousness while the impact of the territory is rather unilateral due to geographical determination. Altogether, the axiological field is the most notable overlapping area because of the ubiquity of value system in both notions studied. The prospects for further exploration of the interrelations between national self-consciousness and historical myths are conditioned by the topical necessity to oppose and prevent imperial myths which, unfortunately, take place in the modern world and are generated by unreasonable self-esteem of specific nations. Furthermore, the following studies will allow using the mechanisms of promoting the high level of national self-consciousness in education, adequate informational policies of the state, or subsequent psychological research.

\section{References}

1. Арутюнов С. А. Народы и культуры: развитие и взаимодействие / отв. ред. Ю. В. Бромлей. Москва: Наука, 1989. $246 \mathrm{c}$.

2. Барканова О. В. Динамика национального самосознания личности в период ранней юности: дисс. ... канд. психол. наук: 19.00.13. Красноярск, 2006. 194 с.

3. Барт Р. Мифологии / пер. $з$ фр. С. Засекина. Москва: Академический проект. 2017. 394 с.

4. Бердяев Н. А. Война и эсхатология. Путь. Окт. 1939 - март 1940. № 61. С. 3-14.

5. Борисов В. В. Теоретико-методологічні засади формування національної самосвідомості учнівської та студентської молоді: дис... д-ра пед. наук: 13.00.07. Тернопіль, 2006. 529 с.

6. Боришевський М. Й. Особистість у вимірах самосвідомості: монографія. Суми: Еллада, 2012. 608 с.

7. Гердер И. Г. Идеи к философии истории человечества. Москва: Наука, 1977. 703 с.

8. Гирич І., Шаповал Ю. Чому необхідно переосмислювати минуле? Київ: Фонд Конрада Аденауера. 2010. $44 \mathrm{c.}$

9. Григоріїв-Наш Н. Підстави Української національно-державної політики. Прага; Берлін: Нова Україна, $1923.27 \mathrm{c}$.

10. Коваль 3. Міфи як успішні та стійкі управлінські інформаційно-психологічні проекти. Актуальні проблеми державного управління: зб. наук. пр. ОРІДУ. Одеса: ОРІДУ НАДУ, 2014. Вип. 4 (60). С. 94-98.

11. Кульчицький О. Риси характерології українського народу. Енциклопедія українознавства. Мюнхен Нью-Йорк, 1949. Том 2. С. 708-718.

12. Лебон Г. Психология народов и масс / пер. с фр. А. Фридмана и Э. Пименовой. СПб.: Макет, 1995. $311 \mathrm{c}$.

13. Романенко Ю. М. Мифология конфликта, или Конфронтация образов. Конфликтология. СПб., 2004. № 2. C. $15-20$.

14. Соколова В. Ф. Психологічні особливості розвитку національної самосвідомості студентської молоді засобами української літератури: дис... канд. психол. наук: 19.00.07. Київ, 2005. 196 с.

15. Фрейд 3. Табу девственности. Очерки по психологии сексуальности / пер. Вульф М. Ф. Киев: Здоровье. 1990. C. $128-140$.

16. Чижевський Д. Нариси з історії філософії на Україні. Філософські твори: у 4 т. Київ: Смолоскип, 2005. Т. 1: Нариси з історії філософії на Україні. Філософія Григорія Сковороди. 2005. 400 с.

17. Шугай М. А. Психологічний аналіз розвитку національної рефлексії в процесі навчальної діяльності молодших школярів: дис... канд. психол. наук: 19.00.07. Острог, 2002. 245 с. 
18. Щербаков В. П. Миф в психоанализе. Серия «Мыслители», Смысль мифа: мифология в истории и культуре. Вып. 8: сборник в честь 90-летия профессора М. И. Шахновича. Санкт-Петербург: Санкт-Петербургское философское общество, 2001. URL: http://anthropology.ru/ ru/text/shcherbakov-vp/mif-v-psihoanalize.

19. Щурко О. Архетип, стереотип і міф в міжнародному образі держави. Гілея: науковий вісник / гол. ред. В. М. Вашкевич. Київ: Гілея, 2016. Вип. 115 (12). С. 411-413.

20. Юнг К. Г. Душа и миф: шесть архетипов / пер. с англ. В. Наукманов. Киев: Государственная библиотека Украины для юношества, 1996. 384 с.

21. Юнг К. Г. Психология бессознательного / пер. с англ. В. Зеленский. Издание 2-е. Москва: КогитоЦентр. 2010. 352 с.

22. Ясь О. В. Міф історичний. Енц̧иклопедія історії України. Т. 6: Ла-Мі / редкол.: В. А. Смолій (голова) та ін. Київ: Наукова думка, 2009. 790 с.

23. May R. The Cry for Myth. New York: W. W. Norton \& Company, 1991. 324 p.

24. Myths and nationhood / G. Hosking and G. Schopflin (eds.). New York: Routledge, 1997. 256 p.

25. Romanucci-Ross L. Ethnic Identity: Creation, Conflict, and Accommodation. 1995. 400 p.

26. Segesten A. D. Myth, Identity and Conflict: A Comparative Analysis of Romanian and Serbian Textbooks. Lanham: Lexington Books, 2011. 314 p.

27. Seton-Watson H. Nations and States: An Enquiry into the Origins of Nations and the Politics of Nationalism.

Boulder, Colorado: Westview, 1977. 563 p.

28. Streth B. A European Identity. To the Historical Limits of a Concept. European Journal of Social Theory. 2002. Vol. 5. No. 4. P. 387-401.

29. Torrecilla J. Spannish Identity: Nation, Myth, and History. Studies in 20th \& 21st Century Litertature. Vol. 33. Is. 2. Article 2. P. 204-226. 